\title{
Evaluation of Bone Mineral Density and Bone Turnover Markers in Patients with non-Cirrhotic Chronic Hepatitis B
}

\author{
Sirotik Olmayan Kronik Hepatit B'li Hastalarda \\ Kemik Mineral Yoğunluğu ve \\ Kemik Döngüsü Göstergelerinin \\ Değerlendirilmesi
}

Güven ÇELEBI, MD, Assoc.Prof., ${ }^{a}$ Selda SARIKAYA, MD, Assoc.Prof., Şenay ÖZDOLAP, MD, Assoc.Prof., ${ }^{b}$ Görkem MUNGAN, MD, Assoc.Prof., Handan ANKARALI, Dr, Prof., ${ }^{\circledR}$ Yavuz ÇELIK, MD, Msc, ${ }^{\text {e }}$ Deniz AKDUMAN, MD, Prof. ${ }^{a}$

\section{Departments of}

aInfectious Diseases and

Clinical Microbiology,

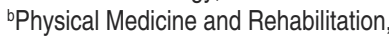
'Biochemistry,

Zonguldak Karaelmas University

Faculty of Medicine, Zonguldak

dDepartment of Biostatistics,

Düzce University Faculty of Medicine,

Düzce

eDepartment of Infectious Diseases and Clinical Microbiology,

Kütahya State Hospital, Kütahya

Geliş Tarihi/Received: 16.01.2011

Kabul Tarihi/Accepted: 27.11.2011

Yazıșma Adresi/Correspondence: Güven ÇELEBI, MD, Assoc.Prof. Department of Infectious Diseases and Clinical Microbiology,

Zonguldak Karaelmas University Faculty of Medicine, Zonguldak, TÜRKIYE/TURKEY

guvencelebi@yahoo.com

\begin{abstract}
Objective: To evaluate the bone mineral density (BMD) and the biochemical markers of bone turnover in non-cirrhotic chronic hepatitis B patients. Material and Methods: We compared 18-65 years old non-cirrhotic chronic hepatitis B patients and healthy controls for BMD and biochemical markers of bone turnover. BMD was measured at the lumbar spine and the left hip using DXA. Results: There were 31 hepatitis B patients (19 males, 12 females) and 72 healthy controls (56 males, 16 females) in the study. Their mean age was $37.4 \pm 10.0$ years in the study group and 38.5 \pm 7.1 years in the controls. There were no differences between the two groups for the mean BMD levels and T scores. However, left hip BMD and T scores were significantly lower in male patients with chronic hepatitis B infection when compared to males in the control group. Serum calcium, phosphate, osteocalcine, intact parathyroid hormone, deoxypyridinoline and 25-hydroxycholecalciferol levels did not differ between the groups. Conclusion: In our study, left hip BMD and T scores were found to be significantly lower in the male patients with chronic hepatitis B infection when compared to males in the control group, however a significant difference was not detected when all cases were compared with the control group. Therefore, we suppose that further studies on a larger population are needed in this issue.
\end{abstract}

Key Words: Hepatitis B virus; chronic hepatitis B; bone density

ÖZET Amaç: Sirotik olmayan kronik hepatit B'li hastalarda kemik mineral yoğunluğu (KMY) ve kemik döngüsü biyokimyasal parametrelerini değerlendirmektir. Gereç ve Yöntemler: Yaşları 18-65 arasında olan, sirotik olmayan kronik hepatit B'li hastaların ve sağlıklı olguların KMY ve kemik döngüsü biyokimyasal parametrelerini karşılaştırdık. KMY ölçümü, DXA yöntemi ile lomber omurga ve sol kalça bölgesinden yapıldı. Bulgular: Çalışmaya 31 hepatit B hastası (19 erkek, 12 kadın) ve 72 sağlıklı kişi (56 erkek, 16 kadın) alınmıştır. Yaş ortalaması kronik hepatit B'li grupta 37,4 10 yıl, sağlıklı kontrol grubunda 38,5 7,1 yıl olarak hesaplandı. Ortalama KMY değerleri ve T skorları açısından iki grup arasında anlamlı fark saptanmadı. Ancak, sol kalça KMY ve T skorları kronik hepatit B'li erkek hastalarda kontrol grubundaki erkeklere göre anlamlı ölçüde daha düşük bulunmuştur. Serum kalsiyum, fosfat, osteokalsin, aktif parathormon, deoksipiridinolin ve 25-hidroksikalsiferol seviyeleri yönünden iki grup arasında anlamlı fark saptanmamıştır. Sonuç: Çalışmamızda kronik hepatit B'li erkek hastaların sol kalça KMY ve T skorları sağlıklı erkeklere göre anlamlı düzeyde düşük bulunmuştur ancak tüm vakalar kontrol grubu ile karşılaştırdığında anlamlı bir fark saptanmamıştır. Bu nedenle bu konuda daha geniş vaka grupları ile yapılacak ileri çalışmalara gerek olduğunu düşünmekteyiz.

Anahtar Kelimeler: Hepatit B virüsü; kronik hepatit B; kemik yoğunluğu

Turkiye Klinikleri J Med Sci 2012;32(2):324-30

doi: 10.5336/medsci.2011-22718

Copyright $(\mathcal{C} 2012$ by Türkiye Klinikleri lteration in mineral amount of bone is a common complication of chronic liver disease. ${ }^{1,2}$ Hepatic osteodystrophy, described by Heaf, is a general definition that describes abnormalities in mineral density 
and bone metabolism in individuals with chronic liver disease. ${ }^{3}$ Prevalence of osteoporosis has been reported between $9 \%$ and $100 \%$ among the patients with chronic liver diseases in which cholestatic disorders and alcoholic liver disease have the highest rates. ${ }^{4-8}$ Imbalance between osteoblast-meditated bone formation and osteoclast-induced bone resorption is considered as the main mechanism of osteoporosis in progressive liver disease. ${ }^{1,2}$ The elements in potential mechanism of bone loss in progressive liver disease are hypothesized as hypogonadism (estrogen and testosterone deficiency), reduced hepatic hydroxylation of vitamin $\mathrm{D}$, reduced osteoblastic activity associated with impaired hepatic production of insulin-like growth factor-1, increased osteoclastic activity due to impaired hepatic production of osteoprotegrin and increased level of proinflammatory cytokines. ${ }^{1,2}$ Osteodystrophy in patients with liver cirrhosis secondary to viral hepatitis has been well defined; however, there is little information about occurrence of bone disease in non-cirrhotic patients with chronic viral hepatitis, especially in asymptomatic hematite B virus (HBV) carriers. ${ }^{9-13}$ Therefore, the aim of this study was to evaluate the bone mineral density (BMD) and the biochemical markers relevant the bone turnover in non-cirrhotic patients with chronic viral hepatitis B.

\section{MATERIAL AND METHODS}

This prospective study was conducted according to the "Declaration of Helsinki-Ethical Principles for Medical Research Involving Human Subjects" in Zonguldak University Hospital. The study protocol was approved by ethical committee of our hospital and a written informed consent was obtained from each subject. We compared 18-65 years old non-cirrhotic chronic hepatitis B patients and agegender adjusted healthy controls for BMD and biochemical markers of bone turnover. The control group consisted of the subjects who were randomly selected from an otherwise healthy population aged between 18-65 years and had a negative serology for HIV, HCV and HBsAg.

Chronic hepatitis $\mathrm{B}$ was defined as being positive for HBsAg for more than six months. The case group was consisted of the chronic hepatitis B pati- ents who were evaluated with detailed clinical examination, abdominal ultrasonography (USG), and routine laboratory measurements with 6-12 months intervals in our institution. An inactive $\mathrm{HBs} A g$ carrier was defined as a patient who had been positive for HBsAg for more than six months, had persistently normal ALT levels on repeated measurements during a follow-up period of at least one year and a negative or a low level $\left(<10^{4} \mathrm{copy} / \mathrm{ml}\right)$ of HBV-DNA. ${ }^{14,15}$ Liver biopsy was not routinely implemented for the patients with chronic hepatitis B, however, patients who had elevated ALT levels (1.5 or more times higher than the upper limit of normal value) or high level of HBV-DNA ( $\geq 10^{4} \mathrm{copy} / \mathrm{ml}$ ) were evaluated with a liver biopsy. Chronic hepatitis B patients who were diagnosed as cirrhosis with liver biopsy or who had any finding (clinical, laboratory or imaging) compatible with liver cirrhosis were not included in this study.

Exclusion criteria: The patients in the case group who were concurrently positive for HIV, HCV or HDV were excluded. The participants of the study who had a positive history of the following systemic diseases and disorders were excluded either from the case group or the control group: diabetes mellitus, chronic renal disease, thyroid diseases, parathyroid diseases, current or previous malignancy, connective tissue diseases, current or previous alcohol abuse, previously diagnosed osteoporosis, being on medications for osteoporosis, hormone therapy or any medication affecting bone metabolism such as steroids, anti-epileptics, heparin etc. Postmenopausal females were also excluded in both groups.

\section{BONE MINERAL DENSITY MEASUREMENTS}

Bone mineral density was measured at the lumbar spine (L1-4) and the left hip (total hip) using DXA (Hologic QDR4500W, Hologic, Inc Bedford, USA). The results were measured on $\mathrm{g} / \mathrm{cm}^{2}$ and the number of standard deviation (SD) based on a comparison with peak bone mass ( $\mathrm{T}$ score). The precision error for the lumbar spine, hip and forearm were $1 \%$ for all regions. For quantification of bone mass loss, World Health Organization (WHO) criteria which were defined for postmenauposal women was used: ${ }^{16}$ Normal BMD is defined as BMD $<-1$ 
SD below mean normal young adult BMD, osteopenia is defined as BMD between -1 and -2.5 SD below mean normal young adult BMD and osteoporosis is defined as $\mathrm{BMD}>-2.5 \mathrm{SD}$ below mean normal young adult BMD.

\section{BIOCHEMICAL MEASUREMENTS}

Blood was drawn in the morning after an overnight fasting. Serum was analyzed for glucose, calcium $(\mathrm{Ca})$, phosphate $(\mathrm{P})$, alkaline phosphatase (ALP), alanine amino transferase (ALT), aspartate amino transferase (AST)and urea, and urine and serum creatinine spectrophotometric analysis was performed with Cobas Integra 800 (Roche Diagnostics, Mannheim, Germany). Free T3, free T4, TSH and intact parathyroid hormone (iPTH) levels were measured using chemiluminescent immunometric assay with Immulite 2000 (BioDPC, LA, US). Osteocalcine was measured using chemiluminescent immunometric assay with Immulite One (BioDPC, LA, US). Deoxypyridinoline (DPD) was measured using chemiluminescent enzyme labeled assay with Immulite One ( BioDPC, LA, US). DPD and urine creatinine (UCr) was measured using the second morning urine or from 24-h collection specimens using standardized commercial assays. To correct for variations in urinary flow, DPD results should be normalized according to the urinary creatinine concentration, and expressed as nanomoles DPD, per liter divided by milimoles creatinine per liter (nM DPD/ mM creatinine)(Urinary excretion was expressed as the ratio of DPD to UCr.) 25-hydroxycholecalciferol [25(OH) D3] (Immundiagnostik AG, Bensheim and Biomedica,Wien) was measured by competitive ELISA assays with LP-400 ELISA (Pasteur Diagnostics,FR) system. All samples were stored at $-70^{\circ} \mathrm{C}$ until tested.

\section{STATISTICAL ANALYSIS}

Descriptive values were calculated as mean \pm standad deviation (SD), count and percent. Normality test were done for continuous variables by using Kolmogorov-Smirnov test. After that, student t-test or MannWhitney U test for two independent two groups and Pearson Chi-square test were used first because unadjusted $\mathrm{p}$ values were obtained. After,
Covariance analysis was used for differences between groups, sex and its interactions on markers of bone metabolism for adjusting $\mathrm{p}$ values were obtained. In this analysis age, body mass index (BMI), smoking, alcohol intake, daily calciums intake, ALT, AST, ALP, glucose, urea, creatine, Ca, P, TSH, free $\mathrm{T} 3$ and free $\mathrm{T} 4$ were accepted covariates. Type I error probability was accepted as $5 \%$.

\section{RESULTS}

There were 31 (19 males, 12 females) patients with chronic hepatitis B in the case group and 72 (56 males, 16 females) healthy individuals in the control group. All females in both groups were premenopausal. In case group, 28 patients were $\mathrm{HBeAg}$ negative and anti-HBeAg positive and the remaining three were $\mathrm{HBeAg}$ positive and anti-HBeAg negative. Among hepatitis $B$ patients, 28 were inactive HBsAg carriers and the remaining three had mild hepatitis according to Knodell histological activity score in liver biopsy. The mean age was $37.4 \pm 10.0$ years in case group and $38.5 \pm 7.1$ years in the controls. There were statistically significant differences between the mean values of (cases and controls respectively) AST $(27.2 \pm 13.4$ and $20.0 \pm 5.0 \mathrm{U} / \mathrm{L}$, $\mathrm{p}<0.001)$, urea $(23.7 \pm 6.4$ and $28.2 \pm 7.4 \mathrm{mg} / \mathrm{dL}$, $\mathrm{p}=0.004)$, free T3 $(3.50 \pm 0.4$ and $2.0 \pm 0.3 \mathrm{pg} / \mathrm{mL}$, $\mathrm{p}<0.001)$ TSH $(1.23 \pm 0.9$ and $1.65 \pm 1.2 \mu \mathrm{IU} / \mathrm{mL}$, $\mathrm{p}=0.027)$ and free $\mathrm{T} 4(1.19 \pm 0.2$ and $0.89 \pm 0.2 \mathrm{ng} / \mathrm{dL}$, $\mathrm{p}<0.001)$. However, TSH, free T3 and free T4 levels were all in normal range in both groups. In hepatitis B group, daily calcium intake was insufficient for $83.9 \%$ of the cases whereas insufficient daily calcium intake was evident in $26.4 \%$ of the controls and the difference was statistically significant $(\mathrm{p}<0.001)$. Demographic features and the baseline values of serum biochemical parameters of the hepatitis $\mathrm{B}$ patents and the controls are shown in Table 1.

\section{COMPARISONS OF BIOCHEMICAL MARKERS OF BONE TURNOVER}

The mean serum iPTH levels in the cases and the controls were $48.9 \pm 16.8$ and $40.0 \pm 14.7$, respectively. The difference was statistically significant with student- $T$ test ( $\mathrm{p}=0.010$ ); however, it was not with covariance analysis $(\mathrm{p}=0.918)$. There was a 
TABLE 1: Demographic characteristics and the mean values of serum biochemical parameters of the hepatitis $B$ patients and the controls.

\begin{tabular}{|c|c|c|c|}
\hline Variable & $\begin{array}{l}\text { Chronic Hepatitis B patients } \\
\qquad(n=31) \\
\text { Mean } \pm S D,(\text { min-max }) \text { or }(\%)\end{array}$ & $\begin{array}{c}\text { Control group } \\
(n=72) \\
\text { Mean } \pm S D,(m i n-m a x) \text { or }(\%)\end{array}$ & p value \\
\hline Age & $37.4 \pm 10.0(20-54)$ & $38.5 \pm 7.1(26-58)$ & 0.524 \\
\hline Sex & & & 0.086 \\
\hline Male & $19(61.3 \%)$ & $56(77.8 \%)$ & \\
\hline Female & $12(38.7 \%)$ & $16(22.2 \%)$ & \\
\hline $\mathrm{BMI}\left(\mathrm{kg} / \mathrm{m}^{2}\right)$ & $24.89 \pm 3.5(13.60-30.50)$ & $26.78 \pm 4.1(19-37.5)$ & 0.027 \\
\hline Smoking & $11 / 31(35.5 \%)$ & $17 / 72(23.6 \%)$ & 0.218 \\
\hline Alcohol use & $5 / 31(16.1 \%)$ & $3 / 72(4.2 \%)$ & 0.038 \\
\hline Daily Ca intake & & & $<0.001$ \\
\hline Insufficient & $26(83.9 \%)$ & $19(26.4 \%)$ & \\
\hline Medium & $5(16.1)$ & $36(50.0 \%)$ & \\
\hline Sufficient & $0(0 \%)$ & $2(2.8 \%)$ & \\
\hline ALT & $33.3 \pm 27.1(8-124)$ & $25.6 \pm 11.8(9-69)$ & 0.386 \\
\hline AST & $27.2 \pm 13.4(14-77)$ & $21.0 \pm 5.0(9-34)$ & $<0.001$ \\
\hline ALP & $68.8 \pm 23.6(34-145)$ & $73.9 \pm 27.9(32-249)$ & 0.377 \\
\hline Glucose & $89.6 \pm 13.8(70-153)$ & $93.9 \pm 11.4(73-155)$ & 0.101 \\
\hline Urea & $23.7 \pm 6.4(10-40)$ & $28.2 \pm 7.4(4-48)$ & 0.004 \\
\hline Creatinine & $0.7 \pm 0.2(0.5-1.1)$ & $0.8 \pm 0.1(0.3-1.2)$ & 0.57 \\
\hline Calcium & $9.5 \pm 0.5(7.7-10.2)$ & $9.6 \pm 0.5(7.8-10.6)$ & 0.915 \\
\hline Phosphate & $3.3 \pm 0.5(2.5-4.5)$ & $3.3 \pm 0.6(1.9-5.0)$ & 0.648 \\
\hline TSH & $1.23 \pm 0.9(0.36-4.50)$ & $1.65 \pm 1.2(0.36-5.00)$ & 0.027 \\
\hline Free T3 & $3.50 \pm 0.4(2.20-4.20)$ & $2.00 \pm 0.3(1.56-3.36)$ & $<0.001$ \\
\hline Free T4 & $1.19 \pm 0.2(0.8-1.60)$ & $0.89 \pm 0.2(0.8-1.95)$ & $<0.001$ \\
\hline
\end{tabular}

ALT (normal range < $42 \mathrm{U} / \mathrm{L}$ ), AST (normal range < $37 \mathrm{U} / \mathrm{L}$, ALP (normal range for females 35-108 IU/L, for males 40-129 IU/L), glucose (normal range 70-110 mg/dL), urea (normal range 10-50 mg/dL,) creatinine (normal range(0,5-1,2 mg/dL), calcium (normal range 8.4-10.2 mg/dL), phosphate (normal range 2.5-4.5 mg/dL), TSH (normal range 0.4-5.0 $\mu / \mathrm{l} / \mathrm{mL}$ ), free T3 (normal range 1.6-4.7 pg/mL), free T4 (normal range 0.8-1.9 ng/dL). SD: Standard deviation; BMl: Body mass index.

statistically significant difference in the mean DPD levels between the cases and the controls $(7.2 \pm 2.6$ and $6.1 \pm 1.8$, respectively) with student $\mathrm{T}$ test $(\mathrm{p}=0.020)$. However, the difference was not statistically significant with covariance analysis ( $\mathrm{p}=0.557)$. The mean values of İPTH and $25(\mathrm{OH}) \mathrm{D} 3$ were not statistically significant different between the groups (Table 2).

\section{COMPARISONS OF BMD MEASUREMENTS}

The mean values of lumbar spine BMD in chronic hepatitis B patients and in controls were similar $(1.017 \pm 0.1$ and $1.049 \pm 0.1$, respectively). No statistically significant differences were detected between the groups in comparisons of lumbar spine T sore, total femur BMD or total femur T score (Table 2).
In comparisons for each gender separately (male versus male and female versus female), there was no significant difference between the females of the two groups; however in males, total femur BMD (0.990 versus $1.176 \mathrm{p}=0.007)$ and total femur T score $(-0.29$ versus $0.92, \mathrm{p}=0.009)$ were higher in male controls. The differences were statistically significant with covariance analysis (Table 3 ).

\section{DISCUSSION}

The mechanism of osteoporosis associated with chronic liver disease is not completely understood, however as in senile osteoporosis, imbalance between osteoblast-meditated bone formation and osteoclast-induced bone resorption is believed to be the main reason of osteoporosis in chronic liver dis- 
TABLE 2: Comparisons of bone metabolism markers and BMD values between the hepatitis B patients and the controls.

\begin{tabular}{|c|c|c|c|c|}
\hline Variable* & $\begin{array}{l}\text { Chronic Hepatitis B patients } \\
\qquad \begin{array}{l}(n=31) \\
\text { mean } \pm \text { SD min-max })\end{array}\end{array}$ & $\begin{array}{c}\text { Control group } \\
(n=72) \\
\text { mean } \pm S D \text { (min-max) }\end{array}$ & $\begin{array}{l}\text { Unadjusted } p \text { value } \\
\text { according to student-T test }\end{array}$ & $\begin{array}{l}\text { Adjustable } p \text { value } \\
\text { according to Covariance analysis }\end{array}$ \\
\hline Osteocalcine & $8.7 \pm 5.5(1.2-21.3)$ & $8.0 \pm 4.5(1.0-25.8)$ & 0.541 & 0.616 \\
\hline iPTH & $48.9 \pm 16.8(19.9-84.0)$ & $40.0 \pm 14.7(17.0-77.5)$ & 0.010 & 0.918 \\
\hline DPD & $7.2 \pm 2.6(2.8-15.0)$ & $6.1 \pm 1.8(3.2-13.4)$ & 0.020 & 0.557 \\
\hline $25(\mathrm{OH}) \mathrm{D} 3$ & $64.9 \pm 61.0(2.7-227.0)$ & $41.9 \pm 49.9(1.6-202.0)$ & 0.080 & 0.216 \\
\hline Lumbar spine BMD $\left(\mathrm{g} / \mathrm{cm}^{2}\right)$ & $1.017 \pm 0.1(0.751-1.260)$ & $1.049 \pm 0.1(0.847-1.443)$ & 0.182 & 0.141 \\
\hline Lumbar spine T score & $-0.50 \pm 1.0(-3.1-1.7)$ & $-0.27 \pm 1.0(-2.2-3.2)$ & 0.281 & 0.174 \\
\hline Total femur BMD $\left(\mathrm{g} / \mathrm{cm}^{2}\right)$ & $0.969 \pm 0.1(0.718-1.326)$ & $1.037 \pm 0.1(0.705-1.358)$ & 0.030 & 0.344 \\
\hline Total femur T score & $-0.20 \pm 0.9(-1.9-1.9)$ & $0.14 \pm 0.9(-1.9-2.1)$ & 0.076 & 0.491 \\
\hline
\end{tabular}

Osteocalcine (normal range 3.1-13.7 ng/mL). iPTH (normal range 10-87 pg/mL), DPD (normal range for male 2.3-5.4 for female 3.0-7.4 nM DPD/ mM creatinine), [25(OH)D3] (normal range $25-125 \mathrm{nmol} / \mathrm{L})$.

* In this analysis age, body mass index, smoking, alcohol intake, daily Ca intake, ALT, AST, ALP, glucose, urea, creatine, Ca, P, TSH, free T3 and free T4 were accepted covariates. SD: Standard deviation.

\begin{tabular}{|c|c|c|c|c|c|c|}
\hline \multirow[b]{2}{*}{ Variable* } & \multirow[b]{2}{*}{$\begin{array}{l}\text { Chronic Hepatitis B } \\
\text { patients } \\
(n=19) \\
\text { mean } \pm S D\end{array}$} & \multirow{2}{*}{$\begin{array}{c}\text { Male } \\
\text { Control group } \\
\qquad(n=56) \\
\text { mean } \pm S D\end{array}$} & \multirow[b]{2}{*}{$\begin{array}{l}\text { Adjustable } p \text { value } \\
\text { according to } \\
\text { Covariance analysis }\end{array}$} & \multicolumn{3}{|c|}{ Female } \\
\hline & & & & $\begin{array}{c}\text { Chronic Hepatitis B } \\
\text { patients } \\
(n=12) \\
\text { mean } \pm S D\end{array}$ & $\begin{array}{l}\text { Control group } \\
\qquad \begin{array}{c}(n=16) \\
\text { mean } \pm S D\end{array}\end{array}$ & $\begin{array}{l}\text { Adjustable } p \text { value } \\
\text { according to } \\
\text { Covariance analysis }\end{array}$ \\
\hline Osteocalcine & $6.6 \pm 2.7$ & $9.8 \pm 1.8$ & 0.286 & $8.4 \pm 6.1$ & $11.0 \pm 7.5$ & 0.814 \\
\hline iPTH & $35.7 \pm 9.4$ & $36.3 \pm 6.4$ & 0.955 & $16.5 \pm 25.9$ & $68.5 \pm 20.9$ & 0.263 \\
\hline DPD & $6.4 \pm 1.2$ & $6.9 \pm 0.9$ & 0.906 & $3.09 \pm 3.5$ & $13.6 \pm 4.6$ & 0.281 \\
\hline 25(OH)D3 & $97.1 \pm 44.6$ & $52.7 \pm 18.6$ & 0.335 & $100.7 \pm 95.4$ & $79.3 \pm 110.7$ & 0.383 \\
\hline Lumbar spine BMD (g/cm2) & $1.040 \pm 0.06$ & $1.182 \pm 0.04$ & 0.05 & $1.043 \pm 0.2$ & $0.864 \pm 0.2$ & 0.578 \\
\hline Lumbar spine T score & $-0.44 \pm 0.6$ & $0.81 \pm 0.4$ & 0.05 & $0.31 \pm 1.3$ & $-2.57 \pm 1.5$ & 0.298 \\
\hline Total femur BMD (g/cm2) & $0.990 \pm 0.06$ & $1.176 \pm 0.04$ & 0.007 & $1.013 \pm 0.2$ & $0.706 \pm 0.2$ & 0.374 \\
\hline Total femur T score & $-0.29 \pm 0.4$ & $0.92 \pm 0.3$ & 0.009 & $0.62 \pm 1.3$ & $-1.89 \pm 1.6$ & 0.369 \\
\hline
\end{tabular}

* In this analysis age, body mass index, smoking, alcohol intake, daily ca intake, ALT, AST, ALP, glucose, urea, creatine, Ca, P, TSH, free T3 and free T4 were accepted covariates. SD: Standard deviation.

ease. ${ }^{1,2}$ Multiple mechanisms that cause bone loss were described in different types of liver diseases. For instance, elevated levels of interleukin-17 which induces osteoclastic activity is considered to be responsible of bone loss in alcoholic liver disease or oncofetal fibronectin produced by activated stellate cells are suggested to suppress osteoblasts and bone formation in patients with primary biliary cirrhosis. The potential mechanism of bone loss in non-cirrhotic chronic hepatitis B is not clearly known. However, some studies have suggested that elevated levels of serum cytokines associated with viral hepatitis, such as tumor necrosis factor-alpha, interleukin-1 and interleukin-6 may inhibit osteoblast-mediated bone formation or promote osteoclast-induced bone resorption which finally lead to reduced BMD. ${ }^{1,2}$

Osteodystrophy in patients with liver cirrhosis secondary to viral hepatitis has been well defined, however there is limited number of the published studies that investigate bone metabolism in patients with non-cirrhotic viral hepatitis (especially in 
asymptomatic HBV carriers) in Pubmed. ${ }^{9-13}$ In a study performed by Tsuneoka et al. in 1993-1994, 20 non-cirrhotic subjects with chronic viral hepatitis due to HBV ( $\mathrm{n}=8)$ and HCV $(\mathrm{n}=12)$ were compared for bone metabolism with cirrhotic patients and also with age-sex matched healthy volunteers. ${ }^{9}$ BMD was significantly decreased in patients with liver cirrhosis and, to a lesser extent, in patients with chronic hepatitis, compared with healthy subjects. In another study, Schiefke et al. investigated BMD and bone turnover markers in biopsy-proven non-cirrhotic 43 patients ( 30 with HCV and 13 with HBV) with viral hepatitis. ${ }^{12}$ They classified the patients according to Knodell histological staging system and found that the BMD was significantly lower and iPTH level was significantly elevated in more advanced stages of liver disease. The study also demonstrated that BMD and T-scores were lower in patients with chronic hepatitis $C$ than in patients with chronic hepatitis B, but the difference was not statistically significant. In another study published in 2006, Yenice et al. assessed bone metabolism and mineral density in 105 non-cirrhotic chronic viral hepatitis patients (60 HBV and 45 HCV) who were diagnosed with liver biopsy which showed moderate and severe hepatitis activation with elevated serum ALT levels (1.5-2 times higher than normal limits). ${ }^{13}$ They found that the mean $\mathrm{T}$ score (BMD measurements were performed at medial phalanxes) was significantly higher and the mean PTH level was significantly lower in male patients between 20-40 years of age with chronic hepatitis B who were compared with age-sex matched healthy controls. The mean $\mathrm{P}$ level in male patients between 40-65 years old with chronic hepatitis $\mathrm{B}$ and the mean DPD level in postmenopausal female patients with chronic hepatitis B were significantly lower when compared with age-sex matched healthy controls. The characteristics of the patients, the etiologic agents of chronic hepatitis (HBV or HCV), the stage of the liver disease (mild to severe) and the model of statistical analysis had some heterogeneity in the above studies and in the present study. Our study was performed only on the patients with hepatitis $B$, and 28 of them were inactive HBV carriers whereas three of them had mild hepatitis. Therefore, comparing the results of the previous studies and the current study may have some limitations. However, in contrast to Yenice et al.'s study, the mean value of total femur BMD and the mean value of total femur $\mathrm{T}$ score were significantly lower in males with inactive hepatitis B in the current study. ${ }^{13}$ The mean value of iPTH levels was significantly elevated in the chronic hepatitis (B and C) patients with more advanced stages of liver disease in Schiefke et al.'s report. ${ }^{12}$ Similarly, iPTH and DPD levels were significantly higher in patients with inactive hepatitis B in our study. However, the difference was not statistically significant when the statistical analysis was performed with covariance model in our study.

In a recently published study, Lo Re III et al. compared 625 HIV subjects co-infected with hepatitis $B$ or hepatitis $C$ with 612 age-sex adjusted HIV mono-infected individuals for BMD scores. ${ }^{17}$ The mean BMD Z scores at the lumbar spine and femoral neck were lower among hepatitis-co-infected women compared to HIV-mono-infected women either without adjustment or after adjustment in statistical method. In contrast to women, no differences for BMD Z sores (without adjustment or after adjustment) were observed among mono-infected and co-infected men. In our study, however not statistically significant, the mean T score (lumbar spine or total femur) in the patients with hepatitis B was lower than in health individuals. When compared each sex separately, the mean adjusted femur T score in the male patients with hepatitis B was lower than in the healthy males $(\mathrm{p}=0.009)$ while a significant difference for the mean $\mathrm{T}$ score was not observed between the healthy women and the women with hepatitis B.

Chronic inflammatory conditions may stimulate activation of some cytokines such as TNF-alpha, IL-1, IL-3, IL-6, IL-7, IL-11, IL-13, IL17 etc. ${ }^{1,2}$ In many studies serum cytokine levels in the patients with HBV infection (asymptomatic HBV carrier or chronic hepatitis $B$ or acute hepatitis $B$ ) were detected to be higher than in healthy donors. ${ }^{18,19}$ In our study, the mean BMD and T scores were found to be lower in the male patients with hepatitis B than in the healthy males. Serum cyto- 
kine levels in the subjects were not investigated, however the possible mechanism of low BMD and $\mathrm{T}$ scores in the male patients with hepatitis B in our study may be associated with elevated cytokine levels due to chronic inflammation in liver.

There are some limitations in our study. The number of the subjects is relatively small, liver biopsy was not performed in most of the subjects and serum cytokine levels of the patients were not determined. However; the current study serves some clues suggesting that patients with chronic HBV in- fection, even in the asymptomatic carrier status, may have an increased risk for alteration of bone metabolism. Therefore, we suppose that further studies are needed in this issue.

\section{Acknowledgment}

We thank Sibel Kiran (from the Department of Public Health) for her contributions about data analysis and Perihan Sapmaz (from the Department of Physical Medicine and Rehabilitation) for her contributions during data collection.

\section{REFERENCES}

1. Nakchbandi IA, van der Merwe SW. Current understanding of osteoporosis associated with liver disease. Nat Rev Gastroenterol Hepatol 2009;6(11):660-70.

2. Rouillard S, Lane NE. Hepatic osteodystrophy. Hepatology 2001;33(1):301-6.

3. Heaf JG. Hepatic osteodystrophy. Scand J Gastroenterol 1985;20(9):1035-40.

4. Hodgson SF, Dickson ER, Wahner HW, Johnson KA, Mann KG, Riggs BL. Bone loss and reduced osteoblast function in primary biliary cirrhosis. Ann Intern Med 1985;103(6 Pt 1):855-60.

5. Bonkovsky HL, Hawkins M, Steinberg K, Hersh T, Galambos JT, Henderson JM, et al. Prevalence and prediction of osteopenia in chronic liver disease. Hepatology 1990;12(2): 273-80.

6. Gonzalez-Calvín JL, Garcia-Sanchez A, Bellot V, Muñoz-Torres M, Raya-Alvarez E, Salvatierra-Rios D. Mineral metabolism, osteoblastic function and bone mass in chronic alcoholism. Alcohol 1993;28(5):571-9.

7. Diamond T, Stiel D, Lunzer M, Wilkinson M, Posen S. Ethanol reduces bone formation and may cause osteoporosis. Am J Med 1989; 86(3):282-8.
8. Diamond T, Stiel D, Mason R, Lissner D, Bikle D, Wilson S, et al. Serum vitamin D metabolites are not responsible for low turnover osteoporosis in chronic liver disease. J Clin Endocrinol Metab 1989;69(6):1234-9.

9. Tsuneoka K, Tameda Y, Takase K, Nakano T. Osteodystrophy in patients with chronic hepatitis and liver cirrhosis. J Gastroenterol 1996;31(5):669-78

10. Corazza GR, Trevisani F, Di Stefano M, De Notariis S, Veneto G, Cecchetti L, et al. Early increase of bone resorption in patients with liver cirrhosis secondary to viral hepatitis. Dig Dis Sci 2000;45(7):1392-9.

11. Duarte MP, Farias ML, Coelho HS, Mendonça LM, Stabnov LM, do Carmo d Oliveira M, et al. Calcium-parathyroid hormone-vitamin D axis and metabolic bone disease in chronic viral liver disease. J Gastroenterol Hepatol 2001;16(9):1022-7.

12. Schiefke I, Fach A, Wiedmann M, Aretin AV, Schenker E, Borte G, et al. Reduced bone mineral density and altered bone turnover markers in patients with non-cirrhotic chronic hepatitis B or C infection. World J Gastroenterol 2005;11(12):1843-7.

13. Yenice N, Gümrah M, Mehtap O, Kozan A, Türkmen S. Assessment of bone metabolism and mineral density in chronic viral hepatitis. Turk J Gastroenterol 2006;17(4):260-6.

14. Conjeevaram HS, Lok AS. Management of chronic hepatitis B. J Hepatol 2003;38(Suppl 1):90-103.

15. Zhang F, Yao S, Zhang M, Yuan J, Chen X, Zhou B. Roles of circulating soluble interleukin (IL)-6 receptor and IL-6 receptor expression on $\mathrm{CD} 4+\mathrm{T}$ cells in patients with chronic hepatitis B. Int J Infect Dis 2011;15(4):e267-71.

16. Kanis JA. Diagnosis of osteoporosis. Osteoporos Int 1997;7(Suppl 3):108-16.

17. Lo Re V 3rd, Guaraldi G, Leonard MB, Localio AR, Lin J, Orlando G, et al. Viral hepatitis is associated with reduced bone mineral density in HIV-infected women but not men. AIDS 2009;23(16):2191-8.

18. Zhang JY, Zhang Z, Lin F, Zou ZS, Xu RN, Jin $L$, et al. Interleukin-17-producing CD4(+) T cells increase with severity of liver damage in patients with chronic hepatitis $B$. Hepatology 2010;51(1):81-91.

19. Zhang $F$, Yao S, Yuan J, Zhang M, He Q, Yang G, et al. Elevated IL-6 receptor expression on CD4+ $T$ cells contributes to the increased Th17 responses in patients with chronic hepatitis B. Virol J 2011;8:270. 
Copyright of Turkiye Klinikleri Journal of Medical Sciences is the property of Ortadogh Reklam Tanitim ve Yayincilik Turizm Egitim Insaat Sanayi ve Ticaret A.S. and its content may not be copied or emailed to multiple sites or posted to a listserv without the copyright holder's express written permission. However, users may print, download, or email articles for individual use. 